\title{
Public Accountability: Implications of the Conspiratorial Relationship between Political Appointees and Civil Servants in Nigeria
}

\author{
Lanre Olu-Adeyemi ${ }^{1}$, Tomola Marshal Obamuyi ${ }^{2}$ \\ ${ }^{1}$ Department of Political Science \& Public Administration, Adekunle Ajasin University, Akungba Akoko, Nigeria; ${ }^{2}$ Department of \\ Banking \& Finance, Adekunle Ajasin University, Akungba Akoko, Nigeria. \\ Email: lanreoluadeyemi@yahoo.co.uk, tomolaobamuyi@yahoo.co.uk
}

Received October $23^{\text {rd }}, 2009$; revised February $6^{\text {th }}, 2010$; accepted March $7^{\text {th }}, 2010$.

\begin{abstract}
The paper focuses on the conspiratorial relationship between Accounting Officers and Political Appointees in Nigeria and how this merge has affected public accountability. The conspiratorial relationship has led to flagrant and deliberate abuse of best practices and due process all in a bid to steal public funds. The absence of public accountability has also increased the chances of corrupt practices by both the political appointees and civil servants. This paper advocates administrative reform and good governance, encompassing public accountability to ensure that the people are held accountable for their behaviours as a deterrent to corrupt practices.
\end{abstract}

Keywords: Accountability, Political Appointees, Civil Servants, Corruption

\section{Introduction}

In contemporary Nigeria, government has ultimately become inseparable from the day to day life of the citizens. This is because government is now involved in the overall social and economic development as against its traditional role of mere maintaining law and order. Unfortunately, the resources at the disposal of governments continue to dwindle, meaning that governments have to reorder her priorities to meet the needs of the society. The implication is that both the civil servants and the political office holders must cooperate to ensure the achievement of sustainable financial and economic development. They must be responsive to the yearnings and aspirations of the people and be held accountable for their actions and inactions.

However, for some times, the influence of the political appointees has made the civil servants to neglect the issue of accountability in the work place. The World Development Report (2004) places accountability succinctly at the centre of public reform and public service delivery [1]. Public accountability measures the degree to which the community can control (hold accountable) the behaviour of public agents through political institutions [2]. Essentially, public accountability mainly regards matters in the public domain, such as the spending of public funds, the exercise of public authorities, or the conduct of public institutions [3]. Generally, the goals of all public accountability measures are to guarantee that public money is spent most judiciously to ensure that the public actually benefits from public finance. There are many dimensions of accountability found in literature. For instance, a distinction can be found between accountability and transparency [4], and between accountability and responsiveness and participation [5]. However, accountability and controllability may be equated, since an agent is accountable to a principal if the principal can exercise control over the agent [6]. Whatever the dimension from which accountability is seen, the importance is in forcing administrators to trace connections between the past, present and future [7].

In order to strengthen the accountability requirements of public sector spending in Nigeria, government had put in place many agencies to overcome the issues of corruption and wasteful spending. These anti-corruption agencies include the Independent Corrupt Practices and Other Related Offences Commission (ICPC), Economic and Financial Crimes Commission (EFCC) and the budget, due process monitoring unit, which are expected to serve as the watch dogs for public officers who may want to defraud the nation and enrich themselves illegally and hence hold them accountable to the public. For instance, the activities of EFCC have been summarized as follows [8]: 
...about 350 EFCC cases are at an advanced stage of prosecution. About 5,000 people have been arrested over the past three years. There have been about 91 convictions for various corruption crimes and assets worth over $\$ 5$ billion have been seized, confiscated and refunded to the state and victims of crime.

The activities of the anti-corruption agencies, notwithstanding, the basic questions in the minds of the people are: 1) To what extent has the concept of accountability be embedded in public services? 2) Has the introduction of the anti-corrupt agencies had any impact on corrupt practices in Nigeria? 3) Can the conspiratorial roles of the public appointees and civil servants be checkmated by the agencies? The paper, therefore, examined the issue of public accountability in Nigeria, and highlights the effects of the conspiratorial associations between civil servants and political appointees, which in most cases has led to opportunistic behaviours with the hope of corruptly enriching the individuals concerned.

\section{Public Accountability and Corruption Control in Nigeria}

Corruption is pandemic in Nigeria and it has certainly emerged as the major impediment to the development of democracy and the national economy. The scourge has grown to become a way of life of both the governor and the governed as it pervades all sectors of the state. A politician that 'succeeds' at the polls sees any office he/ she occupies as a source of re-coupling his/her electoral expenses. Therefore, in most circumstances, public officers use their positions for private gains while long-term public interests are sacrificed.

Basically, corruption is described as efforts to secure wealth or power through illegal means - private gain at public expense; or a misuse of public power for private benefit [9]. It is a behavior, which violates rules against the exercise of certain types of [duties] for private [gains] - regarding influence [10]. This definition includes such behavior as bribery (use of a reward to pervert the judgment of a person in a position of trust); nepotism (bestowal of patronage by reason of ascribed relationship rather than merit); and misappropriation (illegal appropriation of public resources for private uses). Corrupt practices are so common and pervading in the Nigeria's public service to an extent that citizens find it difficult to develop an alternative to deal with it. Corruption is probably the main means to accumulate quick wealth in Nigeria. Corruption occurs in many forms, and it has contributed immensely to the poverty and misery of a large segment of the Nigerian population.

There are three reasons why corruption thrives in $\mathrm{Ni}$ geria [11]:

1) corrupt leadership lacked the desire and ability to change the moral tone of the country;
2) government domination of the economic sphere significantly enhances opportunities and ability to seek rents; and

3) civil society accepts or tolerate corruption

The high level of corruption in Nigeria has been aided by the conspiratorial relationship between political appointees and accounting officers. In this realm, there is flagrant and deliberate abuse of best practices and due process all in a bid to steal public funds. It is possible that either the political appointee or the career civil servant stands as the initiator of the dirty deals or ideas but the long and short of the matter is that both parties conspire against the State and the welfare of her citizens. The history of governance process in Nigeria reflects active connivance between political appointees and career officers at all levels of administration - Federal, State and Local. The situation is such that political appointees and career officers embark on a stealing spree and also use accounting techniques to cover up their tricks. This is evidenced by the blatant squandering of public resources by the past leaders in Nigeria. Reportedly, in 2005, Nigeria, with the assistance of the World Bank, began to recover US $\$ 458$ million of illicit funds that had been deposited in Swiss bank by the late Sani Abacha, who ruled Nigeria from 1993 and 1998.

Honourable Ghali Na'Abba, Speaker of Nigerian House of Representatives (1999-2003), while commenting on the situation of corruption in Nigeria, posits that [12]:

While we cannot rule out the incidence of corruption and bribery in almost every facet of our society, it is particularly resident in the infrastructure areas in ministries or monopolistic parastatals saddled with the task of making infrastructure available to the public - water, telecommunications, electricity (NEPA), roads and railways (NRC) (2003).

The above is not only a confirmation of the malaise in the political economy by a top brass in government; it is also the placement of a national disaster in a well couched language. In the same way, the Nigerian National Petroleum Corporation has been accused of corrupt practices over the years. The corporation had been embroiled in one scandal or the other, ranging from issuance of pro forma invoices (PFIs) to customers and arbitrary product allocations to award of contracts to companies that grease the palms of some unscrupulous NNPC officials so as to secure offshore or downstream contracts [13]. Many corrupt practices have been associated with Public Officers in Nigeria's fourth republic [14].

All the financial gates and scandals unearthed in the Fourth Republic ran into several billions. For instance, the Police boss, Tafa Balogun's financial scam involved the laundering of billions of naira and dollars through different names in banks. Such was the method of gov- 
ernment officials involved in 'Ikoyi-gate', a euphemism for the scam involving the sale of government property in Ikoyi, Lagos and other multiple and serial financial scandals that rocked the Fourth republic from the Local and State Governments to the Presidency.

However, corruption is a phenomenon that presents a paradox in Nigeria. This is because, while the number of cases was declining, the magnitudes in naira term were increasing. This position can be appreciated with the aid of Figure 1 below.

Figure 1 indicates that the number of cases involved in corruption in Nigeria declines progressively since 1999. This period coincides with the introduction of the anti-corruption control measures in the country. But critics believed that the anti-corruption agencies were not effective at controlling corruption [15].

...It is now about four years since your administration embarked upon its anti-corruption crusade. Nevertheless, I regret to observe that the campaign has not yielded the desired result because it lacked focus and strong foundation ab initio.... In any case, the most preposterous and incredulous aspect of your anti-corruption campaign is that while the media is awash with stories on the activi- ties of EFCC and ICPC, corruption is taking root daily in many federal establishments, also rock inclusive. I have said it several times that corruption is rife among senior officials of government, especially those at the federal level.... It is said that a few members of the leadership of the Senate could stoop so low as to drop your name with active connivance of some of your aides to collect large sums in oil and defense contract commissions. The ignominious activities of this cabal, including the foreign accounts of some of your aides, serving and former ministers, are also well known to the international community. I would be surprised if you feign ignorance of this unfortunate situation.

The truth of the matter is that the entire Nigerian political process is hampered by corruption. This also means that accountability has not been rooted in the Nigerian public service. Despite the activities of the ICPC and EFCC, corruption seems to be on the increase in the country. Most times, political appointees see public offices as an avenue to siphon public funds for private ends in spite of the jumbo salaries awarded to themselves by the public officers. For instance, Table 1 shows the annual salaries of certain public officers in Nigeria.

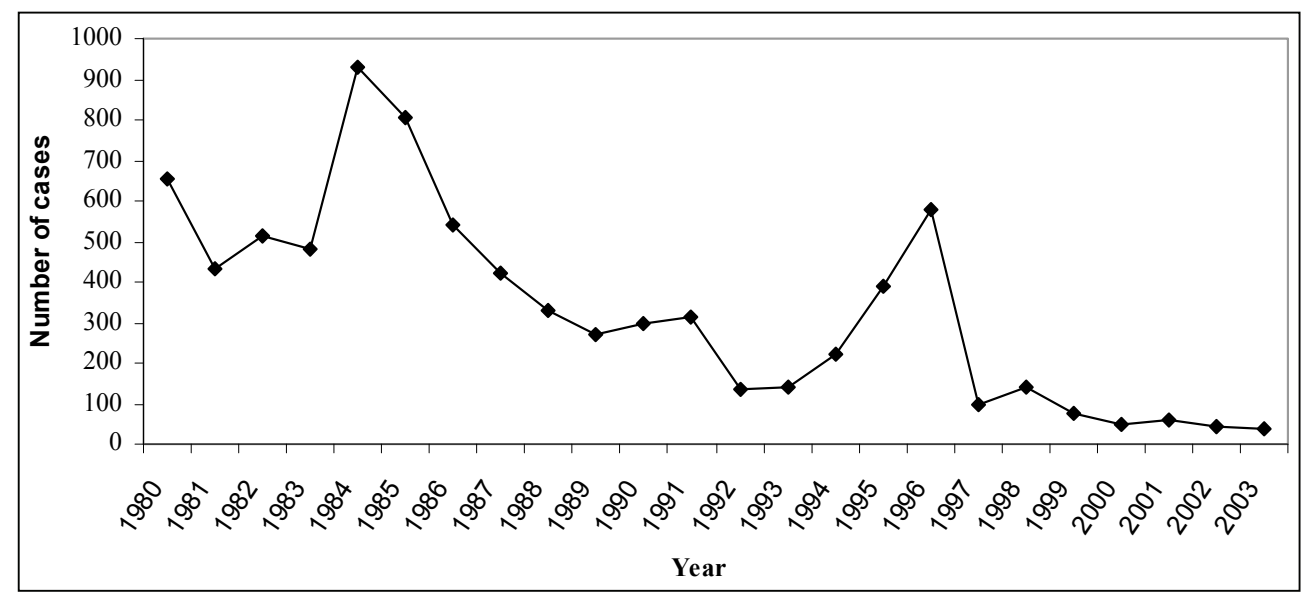

Figure 1. Summary statisticis of corruption in Nigeria (1980-2003)

Table 1. Annual salaries of certain public officers in Nigeria

\begin{tabular}{ll}
\hline & \\
\hline Senator & $36,677,840.00$ \\
Federal House Member & $35,932,346.30$ \\
Federal High Court Judge & $26,875,078.00$ \\
Permanent Secretaries, Executive Secretary, & \\
Chief Executive of Parastatal, Vice Chancellor & $22,051,154.30$ \\
Local Government Chairman & $13,865,895.30$ \\
Local Government Supervisory Councilor & $12,746,875.00$ \\
\hline
\end{tabular}

Source: Culled from ASUU Open Letter to President Umaru Yar'Adua, The Nation, 3 September 2009 
However, political appointees, most of the times, rely on the accounting officers to accomplish their nefarious activities. In actual fact, most of them are tutored in the act of stealing by accounting officers who possess the requisite knowledge on where public funds are kept and how public funds can be diverted into private pockets. This implies conspiracy between the Accounting Officers and Political Appointees. Therefore, the government must strengthen the corruption control mechanisms put in place to ensure good accountability system, free from any governmental interference, in order to sanitize the public service.

\section{Administrative Reform, Good Governance and Public Accountability}

The problems associated with the financial interactions of Accounting Officers and Political Appointees are not insurmountable. This paper advocates administrative reform and good governance for overcoming the conspiratorial relationship, which has affected public accountability.

1) Administrative Reform: Administrative reform is a political process designed to adjust the relationship between a bureaucrat and other elements in society or within the bureaucracy itself [16]. Succinctly put, administrative reform is:

Power politics in action; it contains ideological rationalization, fights for control of areas, services, and people, political participants and institutions... [17].

Administrative reform has a "moral content" in that it seeks to create a "better" system by removing faults and imperfections. It is usually undertaken to change the status quo for the better. It aims at making the administrative and political structures and procedures compatible with broader goals. Administrative reform sets additional political values to be used as yardsticks against which administrative performance may be judged. Administrative reform involves system diagnosis, that is, examination of administrative systems to detect what is wrong and what can be improved.

From the foregoing, it becomes imperative to emphasize the work of the audit department of every government office. This will discourage undue abuse of public privileges on the part of political appointees and ensure that the career of accounting officers is not at the mercy of Political Appointees. Consequently, external auditors appointed for government agencies and parastatals should ensure that accountability is enforced in the accounting system. This will go a long way in corroborating and safeguarding the judgements and actions of accounting officers and Internal Auditors. Thus, the fear that a politician could sack an un-cooperative accounting officer will be limited because sooner or later, the account profile will reveal the real facts behind the actions of the Accou- nting officers and the Political Appointees.

2) Administrative Good Governance: Good governance inter alias relates to the exercise of political power to manage a nation's affairs [18]. It also means an efficient, independent, accountable and open audited public service which has the bureaucratic competence to help design and implement appropriate policies and manage the public sector [19]. It also entails an independent judicial system to uphold the law and resolve disputes arising in a largely free market economy. The administrative aspect of good governance focuses on the following four main areas of public administration in general and public sector management in particular.

a) Accountability, which in essence means holding officials responsible for their actions;

b) Legal framework for development, which means a structure of rules and laws which provide clarity, predicttability and stability for the private sector, which are impartially and fairly applied to all, and which provide the basis for conflict resolution through an independent judicial system;

c) Information, by which is meant that information about economic conditions, budgets, markets and government intentions is reliable and accessible to all, something which is crucial for private sector calculations;

d) Insistence on transparency, which is basically a call for open government, to enhance accountability, limit corruption and stimulate consultative processes between government and private interests over policy development $[20,21]$.

\section{Conclusions}

The paper focuses on the relationship between Accounting Officers and Political Appointees in Nigeria and how this merge has increased corruption. The relationship goes a long way in determining the success or failure of government policies and projects. The most desirable is a cooperative relationship as it enhances efficient service delivery. However, a conspiratorial or confrontational relationship is usually not in the best interest of the Public/Civil service. The conspiratorial relationship breeds corruption which retards national development. The situation was worsened by successive military regimes that institutionalized corruption in the country. Even, the anticorruption measures put in place have received mixed reactions and their workability in achieving the desired objectives. This paper, therefore, advocates administrative reform and good governance, encompassing public accountability to ensure that the people are held accounttable for their behaviour as a deterrent to corrupt practices.

\section{Acknowledgements}

The authors gratefully acknowledged all the anonymous 
reviewers. The paper also benefited from the work of $\mathrm{M}$. A. Khan and N. Chowdhury, accountability, corruption control and service delivery: governance challenges and future options

\section{REFERENCES}

[1] World Bank World Development Report, "Making Service Work for Poor People," The World Bank and Oxford University Press, Washington, DC, 2003.

[2] S. Eckardt, "Political Accountability, Fiscal Conditions and Local Government Performance - Cross-Sectional Evidence from Indonesia," Public Administration Development, Vol. 28, No.1, 2008, pp. 1-17.

[3] M. Bovens, "Analysing and Assessing Public Accountability: A Conceptual Framework," European Government Papers, Vol. 86, No. C-06-01, 2006.

[4] F. Fisher, "The European Union in the Age of Accountability," Oxford Journal of Legal Studies, Vol. 24, No. 1, 2004, pp. 495-515.

[5] R. Mulgan, "Holding Power to Account: Accountability in Modern Democracies," Pelgrave, Basingstoke, 2003.

[6] A. Lupia, "Delegation and its Perils," In K. Strom, et al., Eds., Delegation and Accountability in Parliamentary Democracies, OUP, Oxford, 2003.

[7] P. T. Hart, "Verbroken Verbindingen. Over de politisering van het verleden en de opkomst van een inquisitiedemocratie," De balie, Amsterdam, 2001.

[8] N. Okonjo-Iweala and P. Osafo-Kwaakor, "Nigeria's Economic Reforms: Progress and Challenges," The Brookings Institutions, New York, Washington, DC, 2007.

[9] M. S. Lipset and G. Lenz, "Corruption, Culture and Markets," In L. E. Harrisson and S. P Huntington, Eds., Culture Matters, New York, 2000.
[10] J. S. Nye, "Corruption and Political Development: A Case-Benefit Analysis," The American Political Science Review, Vol. 3, No. 1, 1967.

[11] J. S. Guseh and E. Oritsejafor, "Government size, Political Freedom and Economic Growth in Nigeria, 19602000," Journal of Third World Studies, Vol. 24, No. 1, 22 March 2007.

[12] U. Na'Abba, "The Nigerian Problem and the Legislative Solution via the Legislative Agenda for Nigeria," The Glitterati, 4-10 May 2003.

[13] O. Bello, "Why Rilwan Lukman Needs to Tackle Corruption in NNPC," Business Day, Lagos, 13 January 2009.

[14] M. Dukor, "Corruption in Nigeria: The Moral Question of Statehood in Africa" In S. Hassan, A. Ebele, J. Fayeye and E. Oriola, Eds., Democracy and Development in Nigeria, Vol. 3, Ilorin, 2006.

[15] O. Kalu, "Working for Posterity to Judge us," Open Letter to President Olusegun Obasanjo, 22 August 2005.

[16] J. D. Montgomery, "Sources of Bureaucratic Reform: Problems of Power, Purpose and Politics," Comparative Administrative Group Occasional Paper, Bloomington, 1967.

[17] G. Caiden, “Administrative Reform," Chicago, 1969.

[18] World Bank, "Governance and Development," World Bank, Washington, DC, 1992.

[19] A. Leftwich, "Governance, Democracy and Development in the Third World," Third World Quarterly, Vol. 14, No. 3, 1993, pp. 605-624.

[20] World Bank World Development Report, "Making Service Work for Poor People," The World Bank and Oxford University Press, Washington, DC, 2003.

[21] A. Leftwich, "Governance, Democracy and Development in the Third World," Third World Quarterly, Vol. 14, No. 3, 1993, pp. 605-624. 